\title{
Public opinion in Australia on restricting smoking in public places
}

\author{
Ian McAllister
}

\begin{abstract}
Objectives - To measure public support in Australia for restricting smoking in public places, and to assess what smoking restrictions already exist within the workplace.
\end{abstract}

Design-A personal interview survey representative of the population resident in all states and territories of Australia, conducted in March and April 1993 by a large market research company.

Setting-Interviews were conducted in the respondents' homes.

Subjects -3500 respondents aged 14 years and older.

Main outcome measures-Support for banning smoking in a variety of workplace settings, smoking prevalence, and workplace smoking policy.

Results - There is strong public support for banning smoking in the workplace $(79 \%)$, in restaurants and cafés $(73 \%)$, and in shopping centres $(71 \%)$. There is less support for smoking bans in public houses and clubs $(42 \%)$ and in open air public places $(16 \%)$. Although support is greater among never-smokers or past smokers, $47 \%$ of heavy smokers still support a workplace smoking ban, compared with $32 \%$ who oppose it. Support for smoking bans is strongest among women, older people, immigrants, and those with higher educational attainments and occupational status. Overall, $66 \%$ of employees report that there is a ban on smoking at their workplace, with $14 \%$ reporting restricted smoking inside the building and $20 \%$ no restrictions. This last group is concentrated among the self-employed and those employed in family businesses. The analyses also suggest that workplace smoking restrictions promote support for smoking bans in other locations.

Conclusions - Government legislation to ban smoking in the workplace, in restaurants and cafés, and in shopping centres has strong public support. Although most of the workforce are employed in smokefree workplaces, many small businesses have few smoking restrictions; the Australian government needs to address this problem. A policy of incrementalism on smoking bans would appear to have the

Department of Politics, University of New South Wales Canberra ACT 2600, Australia

I McAllister
(Tobacco Control 1995; 4: 30-35)

Keywords: smoking restrictions; public opinion workplace

\section{Introduction}

The publicity surrounding the dangers of passive smoking has increased awareness among employers of their responsibilities in ensuring occupational health and safety. In Australia, as in many other countries, this has led to restrictions on smoking in the workplace. ${ }^{1}$ Since December 1987, when Australian domestic air carriers became smoke-free, ${ }^{2}$ smoking has been banned in a wide variety of workplaces, including the federal public service, which introduced a total ban in March $1988,{ }^{3,4}$ and in many other major public and private organisations, such as Australia Post and Telecom, and Australia's largest private sector employer, BHP. ${ }^{5}$ There has also been considerable public debate about restricting smoking in other public places, such as shopping centres, restaurants, and cafés. ${ }^{6-8}$

Occupational health and safety legislation enacted by the Australian states places a duty of care on employers. In practice, this means that employers must do whatever is practical and reasonable to provide employees with a safe workplace. Two legal decisions have meant that, increasingly, this duty-of-care obligation has been interpreted to mean preventing exposure to environmental tobacco smoke (ETS). Firstly, a suit seeking compensation for lung cancer caused by passive smoking succeeded in 1990. The court ruled that there was $75 \%$ probability that a Melbourne bus driver, Sean Carroll, had contracted lung cancer from passive smoking at work. ${ }^{9}$ Secondly, in 1991 the courts ruled that the Tobacco Institute had breached the Trade Descriptions Act by placing an advertisement in a newspaper which said that "there is little evidence and nothing which proves scientifically that cigarette smokers cause disease in non-smokers" ${ }^{10,11}$ In effect, these rulings established the case in Australia for the health consequences of ETS.

Total bans on workplace smoking have strong support among employees. A survey of federal public servants conducted just before the introduction of the total smoking ban in 1988 found that $76 \%$ of those interviewed approved of the ban. Approval among smokers was lower, with $40 \%$ approving compared with $82 \%$ of ex-smokers and $90 \%$ of neversmokers. ${ }^{8}$ A national survey conducted in 1990 found similar levels of support for banning workplace smoking: $76 \%$ of non-smokers supported a total ban, compared with $29 \%$ of smokers. ${ }^{12}$ In general, then, there is strong public support for a total ban on workplace smoking. 
In addition to protecting employees' health, workplace smoking bans also reduce overall smoking consumption as well as provide some assistance for smokers to quit. Surveys conducted before and after the introduction of total smoking bans have found significant reductions in smoking prevalence and consumption. A survey of federal public servants ${ }^{13}$ found that workplace smoking bans were associated with reduced rates of smoking, particularly among heavier smokers where the reduction in consumption was more than $25 \%$. A similar "before and after" study of Telecom staff found that the bans produced a reduction in workday cigarette consumption of between three and four cigarettes a day and this reduction was maintained at 18 months. Over the two-year period of the study-from six months before the ban to 18 months after it smoking prevalence dropped by about $5 \% \cdot{ }^{14}$ Other surveys have indicated significant reductions in consumption of between three and five cigarettes per day. ${ }^{15,16}$

But it is not only in the workplace where smoking has been restricted. There is also pressure to restrict or ban smoking in shopping centres, restaurants and cafés, as well as in public houses and clubs. At present, these locations fall under occupational health and safety legislation, but the provision of smokefree zones or a total ban is voluntary. Surveys consistently have found a large majority in favour of banning smoking in restaurants and this majority has been increasing in recent years. ${ }^{6,7,17}$ To date, however, only the Australian Capital Territory has proposed legislation to restrict smoking in restaurants and cafés. The fate of this legislation may provide an indicator as to how the other Australian states approach the issue.

To what extent is there popular support not only for total bans on smoking in the workplace but also in other public places, such as restaurants, public houses and clubs, and shopping centres? Which social groups are more likely to support such bans? How many employees currently work in areas where smoking is restricted or banned? And does a workplace smoking ban increase support among employees for smoking bans in other locations?

To answer these questions, a major national survey is used, conducted in March and April 1993 as part of a continuing evaluation of drug use by the National Campaign Against Drug Abuse (NCADA), a federally funded initiative which commenced in 1986 with the aims of reducing licit and illicit drug use and increasing popular awareness of the harmful consequence of all forms of drug abuse. ${ }^{18}$

\section{Subjects and methods}

A stratified random sample of 6750 individuals aged 14 years and over were selected for interview in their homes by a large market research company, AGB McNair, during March and April 1993. The survey resulted in 3500 usable interviews, with 1999 refusals and 1251 potential respondents being otherwise uncontactable. This represents an effective response rate of $63.6 \%(3500 / 5499)$, which is comparable with the response rates achieved by the previous surveys in the series. ${ }^{19}$ The survey design oversampled in the smaller states and territories; for this reason, the data are weighted by age by sex by state/territory, based on Australian Bureau of Statistics projections in 1991, to make them nationally representative. The weighted number of respondents is adjusted to the true number interviewed to leave significance tests unaffected. A comparison of age, sex and state/ territory for the unweighted data and the weighted data indicate little variation whereas more detailed comparisons between the 1991 and 1993 NCADA National Household surveys indicate similar distributions.

The questionnaire was designed to collect a range of information about the respondents' attitudes towards drug-related issues, their patterns of drug use, and basic sociodemographic information. Due to the sensitive nature of some of the drug use questions, particularly those relating to illicit drug use, these questions were administered by means of a sealed self-completion booklet, which has proved to be one of the most reliable methods of collecting such data. ${ }^{20-21}$ Other measures that were taken to test the reliability of the responses, such as including a fictitious drug in the interview schedule, suggest that the results are accurate. ${ }^{22}$ The average interview length was 54 minutes.

For the public smoking questions used here, the respondents were asked by the interviewer to give their opinions on a five-point scale about banning smoking in five specific locations. The question wording was:

"To what extent would you support or oppose the following?

- Banning smoking in the workplace.

- Banning smoking in shopping centres.

- Banning smoking in public houses and clubs.

- Banning smoking in restaurants.

- Banning smoking in open air public places (such as parks, beaches, on the street)."

These questions were asked in the first 15 o minutes of the questionnaire, immediately after a series of questions relating to drug information needs and public policy towards alcohol.

The survey also asked respondents who were in the labour force what smoking restrictions, if any, existed at their workplace. This question was asked immediately before questions about employment and economic activity, at the end of the questionnaire. The respondents were able to choose between five options: no restrictions; smoking permitted in their own room only; smoking permitted only in a designated smoking area; smoking permitted only outside the building; and a total ban on smoking, outside as well as inside the building. Because only a small number $(\mathbf{n}=$ 38) said that employees were permitted to smoke in their own room only, these responses have been combined with those who said 
smoking was permitted within a designated area.

Smoking and alcohol prevalence and consumption were asked as part of the sealed booklet section of the questionnaire, which was placed at the end of the questionnaire and occupied, on average, the last 10 minutes of the 54 minute total. In table 2, smoking status is divided into four categories: never-smoker, past smoker, and current smoker, with current smokers being further divided into those who reported consuming 15 cigarettes per day or fewer, and those who consumed more than 15 cigarettes per day. In tables 3 and 4, never- and past smokers are combined to represent nonsmokers, and the two categories of current smokers are combined.

All confidence intervals (CIs) presented below are $95 \%$ confidence intervals.

\section{Results}

The survey confirms the strong popular support that exists for banning smoking in the workplace. Combining the "strongly support" and "support" categories in table 1 shows that a total of $79 \%(\mathrm{CI}=77 \%$ to $80 \%$ ) of those interviewed support a total ban, with only $10 \%(\mathrm{CI}=9 \%$ to $11 \%)$ opposing it. There is also strong support for banning smoking in restaurants $(73 \%, \mathrm{CI}=72 \%$ to $75 \%)$ and in shopping centres $(71 \%, \mathrm{CI}=69 \%$ to $72 \%$ ). In each of these three cases, those who strongly support such a ban outnumber those who are lukewarm in their support. There is, however, less agreement about banning smoking in public houses and clubs and in open air public places, such as parks, beaches, and on the street. Supporters of banning smoking in public houses and clubs narrowly exceed those who oppose it, by just six percentage points $(42 \%, \mathrm{CI}=40 \%$ to $43 \%$, compared with $36 \%, \mathrm{CI}=34 \%$ to $38 \%$ ).

Studies have confirmed the importance of smoking status in determining attitudes towards public smoking. ${ }^{7,13}$ As we would expect, smokers are significantly less likely to support smoking bans than either never-smokers or past smokers. Table 2 indicates that, among never-smokers, $89 \% \quad(\mathrm{CI}=87 \%$ to $90 \%)$ support a workplace smoking ban, compared with $67 \%(\mathrm{CI}=63 \%$ to $71 \%)$ of smokers who consume 15 cigarettes a day or less and $47 \%(\mathrm{CI}=42 \%$ to $51 \%$ ) of heavier smokers. But even among heavier smokers, the largest group is in favour of banning smoking in the tween opposition ( $32 \%, \mathrm{CI}=28 \%$ to $36 \%$ ) and indifference $(21 \%, \mathrm{CI}=18 \%$ to $25 \%$ ). The variations are most striking in the context of public houses and clubs; although $55 \%$ (CI $=52 \%$ to $57 \%$ ) of never-smokers support a smoking ban, the same view is taken by only $8 \%(\mathrm{CI}=6 \%$ to $11 \%$ ) of heavy smokers.

Support for banning smoking in public places is most likely to be found among women and older respondents, even after smoking status has been taken into account. Table 3 shows that, among smokers, support for a workplace smoking ban is 14 percentage points higher among women than among men ( $t=$ $3.50, \mathrm{p}<0.01$ ), whereas among non-smokers the difference is four percentage points $(t=$ $3.15, \mathrm{p}<0.01)$. Those aged over 40 years are generally more likely to support a smoking ban, notably in restaurants, public houses, and clubs. In general, immigrants are more likely to support bans compared with the Australian born, particularly in shopping centres. It is notable, however, that of the 15 sets of comparisons in table 3 for the two smoking groups, among smokers, 11 of the 15 are not statistically significant, compared with four of the 15 among non-smokers. There is, then, a greater range and diversity of opinion among non-smokers.

Socioeconomic status is a major influence on smoking and associated health beliefs ${ }^{12,23}$ and these are underlined by the results for educational level and occupation shown in table 4. These results exclude those still at school or university (for education) or not in the labour force (for occupation). The respondents are divided into three educational categories: those without formal educational qualifications; those who gained a trade certificate or a workplace; the remaining $53 \%$ are split be-

5

;

-

$\therefore$

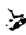

F

5

$x$

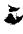

$\div$

$+$

$y$

$r$

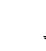

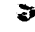

t.

$=$

$x$

2

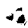

25

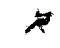

3

$\star$

Table 1 Public opinion (\%) towards smoking in public places

\begin{tabular}{lcccccc}
\hline & $\begin{array}{c}\text { Strongly } \\
\text { support }\end{array}$ & Support & Neither & Oppose & $\begin{array}{c}\text { Strongly } \\
\text { oppose }\end{array}$ & $\begin{array}{c}\text { (Support } \\
- \text { Oppose })\end{array}$ \\
\hline Ban smoking in & & & & & & \\
$\quad$ workplace & 45 & 34 & 11 & 7 & 3 & $(+69)$ \\
restaurants & 40 & 33 & 13 & 10 & 4 & $(+59)$ \\
shopping centres & 37 & 34 & 15 & 11 & 3 & $(+57)$ \\
public houses and clubs & 19 & 23 & 23 & 24 & 12 & $(+6)$ \\
open air public places & 7 & 9 & 24 & 34 & 25 & $(-43)$ \\
\hline
\end{tabular}

Table 2 Support (\%) for smoking bans by smoking status

\begin{tabular}{lccccc}
\hline & $\begin{array}{c}\text { Heavy } \\
\text { smoker } \\
(n=469)\end{array}$ & $\begin{array}{c}\text { Light } \\
\text { smokert } \\
(n=499)\end{array}$ & $\begin{array}{c}\text { Past smoker } \\
(n=469)\end{array}$ & $\begin{array}{c}\text { Never } \\
\text { smoked } \\
(n=469)\end{array}$ & $p \ddagger$ \\
\hline Workplace & 47 & 67 & 83 & 89 & $<0.01$ \\
Restaurant & 39 & 55 & 79 & 85 & $<0.01$ \\
Shopping centres & 42 & 58 & 76 & 79 & $<0.01$ \\
Public houses, clubs & 8 & 16 & 49 & 55 & $<0.01$ \\
Open air public places & 1 & 6 & 14 & 23 & $<0.01$ \\
\hline
\end{tabular}

* More than 15 cigarettes per day.

$\dagger$ Fifteen or fewer cigarettes per day.

$¥$ By $\chi^{2}$ test. 
Table 3 Support (\%) for smoking bans among demographic groups

\begin{tabular}{|c|c|c|c|c|c|c|c|c|c|c|c|}
\hline & \multicolumn{3}{|c|}{ Gender } & \multicolumn{5}{|c|}{ Age } & \multicolumn{3}{|c|}{ Birthplace } \\
\hline & Male & Female & $p^{\star}$ & $14-19$ & $20-39$ & $40-54$ & $55+$ & $p^{\star}$ & Australia & Overseas & $p^{\star}$ \\
\hline $\begin{array}{l}\text { Smokers } \\
\text { Workplace } \\
\text { Restaurants } \\
\text { Shopping centres } \\
\text { Public houses and clubs } \\
\text { Open air public places } \\
\text { Non-smokers }\end{array}$ & $\begin{array}{c}(\mathrm{n}=535) \\
51 \\
48 \\
49 \\
12 \\
3 \\
(\mathrm{n}=1165)\end{array}$ & $\begin{array}{c}(\mathrm{n}=433) \\
65 \\
46 \\
51 \\
13 \\
5 \\
(\mathrm{n}=1314)\end{array}$ & $\begin{array}{l}<0.01 \\
<0.01 \\
\text { ns } \\
\text { ns } \\
\text { ns }\end{array}$ & $\begin{array}{c}(\mathrm{n}=85) \\
59 \\
47 \\
42 \\
7 \\
10 \\
(\mathrm{n}=291)\end{array}$ & $\begin{array}{c}(\mathrm{n}=536) \\
55 \\
46 \\
53 \\
12 \\
4 \\
(\mathrm{n}=862)\end{array}$ & $\begin{array}{c}(\mathrm{n}=227) \\
65 \\
46 \\
47 \\
14 \\
3 \\
(\mathrm{n}=598)\end{array}$ & $\begin{array}{c}(\mathrm{n}=120) \\
51 \\
56 \\
53 \\
13 \\
3 \\
(\mathrm{n}=727)\end{array}$ & $\begin{array}{l}<0.05 \\
\text { ns } \\
\text { ns } \\
\text { ns } \\
\text { ns }\end{array}$ & $\begin{array}{c}(\mathrm{n}=781) \\
57 \\
48 \\
10 \\
51 \\
3 \\
(\mathrm{n}=1918)\end{array}$ & $\begin{array}{c}(\mathrm{n}=187) \\
61 \\
43 \\
21 \\
46 \\
6 \\
(\mathrm{n}=561)\end{array}$ & $\begin{array}{l}\text { ns } \\
\text { ns } \\
<0.01 \\
\text { ns } \\
\text { ns }\end{array}$ \\
\hline $\begin{array}{l}\text { Workplace } \\
\text { Restaurants } \\
\text { Shopping centres } \\
\text { Public houses and clubs } \\
\text { Open air public places }\end{array}$ & $\begin{array}{l}85 \\
82 \\
78 \\
51 \\
18\end{array}$ & $\begin{array}{l}89 \\
85 \\
78 \\
55 \\
22\end{array}$ & $\begin{array}{l}<0.01 \\
\text { ns } \\
\text { ns } \\
<0.05 \\
<0.01\end{array}$ & $\begin{array}{l}85 \\
75 \\
80 \\
38 \\
26\end{array}$ & $\begin{array}{l}87 \\
82 \\
76 \\
52 \\
21\end{array}$ & $\begin{array}{l}91 \\
84 \\
82 \\
61 \\
22\end{array}$ & $\begin{array}{l}85 \\
88 \\
77 \\
54 \\
16\end{array}$ & $\begin{array}{l}<0.01 \\
<0.01 \\
<0.01 \\
<0.01 \\
<0.01\end{array}$ & $\begin{array}{l}88 \\
84 \\
77 \\
51 \\
19\end{array}$ & $\begin{array}{l}86 \\
82 \\
83 \\
59 \\
25\end{array}$ & $\begin{aligned} & \mathrm{ns} \\
& \mathrm{ns} \\
&< 0.01 \\
&< 0.01 \\
&< 0.01\end{aligned}$ \\
\hline
\end{tabular}

$\star \mathrm{By} \chi^{2}$ test. $\mathrm{ns}=$ Not significant at $\mathrm{p}<0.05$.

Table 4 Support (\%) for smoking bans, by education and occupation

\begin{tabular}{|c|c|c|c|c|c|c|c|c|}
\hline & \multicolumn{4}{|c|}{ Education } & \multicolumn{4}{|c|}{ Occupation } \\
\hline & $\begin{array}{c}\text { No } \\
\text { qualifications }\end{array}$ & $\begin{array}{l}\text { Trade, } \\
\text { diploma }\end{array}$ & University & $p^{\star}$ & Manual & Clerical & $\begin{array}{c}\text { Professional, } \\
\text { managerial }\end{array}$ & $p^{\star}$ \\
\hline Smokers & $(\mathrm{n}=616)$ & $(\mathrm{n}=221)$ & $(\mathbf{n}=128)$ & & $(\mathrm{n}=276)$ & $(\mathrm{n}=167)$ & $(\mathrm{n}=84)$ & \\
\hline Workplace & 53 & 58 & 76 & $<0.01$ & 46 & 65 & 80 & $<0.01$ \\
\hline Restaurants & 47 & 49 & 42 & ns & 50 & 40 & 48 & $<0.01$ \\
\hline Shopping centres & 46 & 55 & 62 & $<0.01$ & 50 & 53 & 69 & $<0.05$ \\
\hline Public houses and clubs & 11 & 14 & 13 & $<0.01$ & 12 & 14 & 20 & ns \\
\hline Open air public places & 4 & 3 & 6 & ns & 21 & 6 & 9 & $<0.01$ \\
\hline Non-smokers & $(\mathrm{n}=1495)$ & $(\mathrm{n}=561)$ & $(\mathrm{n}=403)$ & & $(n=415)$ & $(\mathrm{n}=289)$ & $(\mathrm{n}=308)$ & \\
\hline Workplace & 85 & 88 & 95 & $<0.01$ & 81 & 88 & 97 & $<0.01$ \\
\hline Restaurants & 82 & 84 & 87 & $<0.05$ & 78 & 81 & 87 & $<0.05$ \\
\hline Shopping centres & 76 & 79 & 86 & $<0.01$ & 73 & 73 & 88 & $<0.01$ \\
\hline Public houses and clubs & 49 & 55 & 64 & $<0.01$ & 46 & 51 & 66 & $<0.01$ \\
\hline Open air public places & 18 & 22 & 27 & $<0.01$ & 16 & 20 & 25 & $<0.01$ \\
\hline
\end{tabular}

$\star \mathrm{By} \chi^{2}$ test. $\mathrm{ns}=$ Not significant at $\mathrm{p}<0.05$

technical college diploma; and those who attended university. Support for smoking bans is more likely to be found among those who have attended university. For example, no less than $95 \%$ of non-smoking university graduates (CI $=92 \%$ to $97 \%$ ) favour a ban on workplace smoking, compared with $85 \%$ of non-smokers without any educational qualifications $(\mathrm{CI}=82 \%$ to $88 \%)$. The occupational differences in attitudes are even greater; almost twice as many professional or managerial employees who smoke support a ban on smoking in the workplace when compared with manual employees. The results therefore confirm the strong link between higher socioeconomic status and support for smoking bans, even among those who are current smokers.

Widespread public agreement therefore exists on banning smoking in the workplace. To what extent is this reflected in the workplace smoking policies of employers? A survey of the top 600 Australian companies conducted in 1991 found that $77 \%$ of the firms that responded to the survey had restrictions on smoking in the workplace, with $47 \%$ imposing a total ban and $31 \%$ providing a designated smoking area; only $23 \%$ did not have a workplace smoking policy. In general, the larger companies were those which were most likely to have implemented smoking restrictions, with many of the larger companies combining restrictions or bans with cessation programs. $^{24}$

Using the 1993 survey data, table 5 shows that most of those currently in the labour force work in an area where smoking is restricted to outside the building $(53 \%, \mathrm{CI}=50 \%$ to $55 \%$ ) or where there is a ban on smoking outside as well as inside $(13 \%, \mathrm{CI}=11 \%$ to $15 \%)$. One in five of all workers still work in an organisation where there are no restrictions on smoking. As would be expected, government employees are most likely to be in a workplace where smoking is banned $-86 \%$ $(\mathrm{CI}=83 \%$ to $89 \%$ ) reported that this applied at their place of work - whereas $61 \%$ of those employed by private companies reported a ban on smoking within the building or totally.

Nevertheless, nearly half $(48 \%, C I=42 \%$ to $55 \%$ ) of those who are self-employed or who work in family businesses have no workplace smoking restrictions of any kind. Unfortunately, the survey data did not include details about the number of employees in the workplace. However, although some of these workplaces will be based on one person, or include a small number all of whom are smokers (so that no non-smokers are exposed to ETS), it is likely that a proportion of these small workplaces without restrictions employ non-smokers who are exposed to ETS. The private sector, and particularly small businesses, have therefore been slower than the public sector in responding to the requirements of occupational health and safety legislation.

Does a total workplace ban result in changed attitudes towards smoking bans, not just in the workplace but in other locations? Previous research has suggested that once a workplace ban is implemented, opinion increases in support of such bans. ${ }^{5}$ Little is known, however, about whether public attitudes change to 
Table 5 Workplace smoking policy, by type of employer (\%)

\begin{tabular}{lcccc}
\hline & & \multicolumn{3}{c}{ Employer } \\
\cline { 3 - 5 } & $\begin{array}{c}\text { All employees } \\
(n=1611)\end{array}$ & $\begin{array}{c}\text { Government } \\
(n=511)\end{array}$ & $\begin{array}{c}\text { Private company } \\
(n=863)\end{array}$ & $\begin{array}{c}\text { Self-employed } \\
(n=237)\end{array}$ \\
\hline Total ban & 13 & 19 & 11 & 7 \\
Outside only & 53 & 67 & 50 & 34 \\
Designated areas & 14 & 10 & 17 & 11 \\
No restrictions & 20 & 4 & 22 & 48 \\
\hline
\end{tabular}

$\chi^{2}=230.6, \mathrm{df}=6, \mathrm{p}<0.0001$

${ }_{\star}$ Includes employment in family business.

Table 6 Workplace smoking policy and support (\%) for smoking bans, by smoking status

\begin{tabular}{|c|c|c|c|c|c|c|}
\hline & \multicolumn{3}{|c|}{ Smokers } & \multicolumn{3}{|c|}{ Non-smokers } \\
\hline & $\begin{array}{c}\text { No } \\
\text { restrictions }\end{array}$ & Ban & $p \dagger$ & $\begin{array}{c}\text { No } \\
\text { restrictions }\end{array}$ & Ban & $p \dagger$ \\
\hline Workplace & 42 & 69 & $<0.01$ & 81 & 91 & $<0.01$ \\
\hline Restaurant & 41 & 49 & ns & 76 & 86 & $<0.01$ \\
\hline Shopping centres & 45 & 60 & $<0.01$ & 68 & 83 & $<0.01$ \\
\hline Public houses and clubs & 10 & 16 & ns & 44 & 60 & $<0.01$ \\
\hline Open air public places & 3 & 5 & ns & 21 & 21 & ns \\
\hline
\end{tabular}

«No restrictions combines "designated areas" and "no restrictions" in table 5. Ban

combines "total ban" and "outside only" in table 5 .

† By $\chi^{2}$ test. $\mathrm{ns}=$ Not significant at $\mathrm{p}<0.05$.

support bans in other locations, such as restaurants or public houses. The 1993 data enable us to address this question. Table 6 shows support for smoking bans in the five locations, separately by workplace smoking policy and controlling for smoking status. The results show clearly that workers who are employed in organisations where there is a smoking ban are more likely to support smoking restrictions not just in the workplace but in other locations, with the exception of open air public places. The increase in support associated with workplace smoking bans is statistically significant for four of five location types for non-smokers but for only two of five location types for smokers (table 6). Nevertheless, $60 \%$ of smokers who are employed in a non-smoking workplace support a smoking ban in shopping centres, compared with $45 \%$ of their counterparts who work in organisations where there are no restrictions.

\section{Discussion}

As smoking prevalence declines within the population, particularly among men, ${ }^{25}$ there is increasing public pressure in Australia to restrict workplace smoking. This pressure has undoubtedly been increased by the Carroll case and several other well-publicised court actions which have highlighted the occupational health and safety responsibilities of employers..$^{9,11}$ But, although there is broad agreement about banning smoking in the workplace, a vigorous debate has emerged about restricting smoking in other public places, such as restaurants and cafés. The results presented here show strong support for total bans on public smoking in the workplace, but there is also strong support for total smoking bans in restaurants and shopping centres. Supporters of smoking bans in these locations outnumber those who oppose them by between five and six to one. Even among smokers, about half support bans in restaurants and shopping centres.

Despite this overwhelming support for workplace smoking bans, about a third of those in the Australian labour force still work in locations where smoking is either unrestricted or permitted in parts of the workplace, almost all of them in the private sector. In general, these private employers tend to be small businesses and, although they are covered by occupational health and safety legislation, they have been slower than large private organisations to implement smoking restrictions. This is usually because of one or more of the following. (a) They are prepared to take the personal health risk, often because the employers themselves smoke; (b) they perceive that the costs outweigh the benefits of complying with the legislation; and (c) they believe that the risks of being caught violating the law are minimal, the likelihood of being punished is small, and the severity of the sanction is negligible. Large companies have been quicker to ban smoking because there are often occupational health and safety staff who are prepared to take the responsibility and because such organisations possess more resources to run cessation programmes for employees. Both of these have been identified as important elements in the successful implementation of workplace smoking bans. ${ }^{3,26}$

We found that workers employed in organisations where smoking is banned are more likely to support smoking restrictions in the workplace and other public places than employees who work in places where smoking is still permitted. Given the cross-sectional nature of the survey, one cannot make firm conclusions about the causality or direction of this association - for example - workers who support smoke-free environments may cause their worksites to become smoke-free. Another, perhaps more plausible explanation 
for the association is that, once smoking bans are introduced in the workplace, they may have a significant effect in promoting support for further smoking restrictions, not just in the workplace itself but also in other locations. As a wide variety of studies have demonstrated, government restrictions present models that eventually modify behaviour. In the case of smoking, workplace restrictions introduced in response to government initiatives serve to increase generalised support for banning public smoking.

This finding highlights the importance of continued government initiatives to restrict public smoking. Although occupational health and safety regulations will ensure bans on workplace smoking in large organisations, continued difficulties exist in gaining the compliance of smaller organisations that have a small number of smoking and non-smoking employees. If such employers do not believe that policies to restrict smoking are either in the public good or fair, then their compliance will be low. ${ }^{27}$ Gaining the support of small businesses for workplace smoking bans should have a high priority in government policy on smoking.

Outside the workplace, progress to ban smoking has been slower in Australia. Although it is voluntary for restaurants and cafés to provide smoke-free zones, there is a clear public preference for a total smoking ban in such locations, as well as in shopping centres. Such public support should help government to legislate to ban smoking in restaurants, cafés, and shopping centres. The problem of public smoking in public houses and clubs is more difficult, because public opinion is divided on the issue. It may well be more effective to deal with this issue following a ban on smoking in restaurants, after which public opinion may become more receptive to a ban in public houses and clubs.

The 1993 Australian National Campaign Against Drug Abuse Social Issues Survey was funded by the Federal Department of Health and Human Services and made available by the Social Science Data Archive at the Australian National University. My thanks to Margo Goodin, Teresa Lea, Toni Makkai and three anonymous referees from this journal for constructive comments; the usual disclaimer applies.

1 Borland R. The extent of restrictions on smoking in the workplace. F Occup Health Safety 1990; 6: 93-6.

2 Castleden WM, Shean RE. Smoking in aircraft. Med 7 Aust $1987 ; 147: 532-3$
3 McKay BV, Fitzwarryne CM. The Commonwealth Department of Health smoke-free workplace policy. Comm Health Stud 1987; 11: 3-5s.

4 Chapman S. Smoking in the workplace. Lancet 1992; 339: 1614

5 Borland $\mathbf{R}$. Changes in prevalence of and attitudes to restrictions on smoking in the workplace among indoor workers in the state of Victoria, Australia, 1988-90. Tobacco Control 1992; 1: 19-24.

6 Borland R, Hill, DJ. Public attitudes to smoke-free zones in restaurants-an update. Med $\mathcal{f}$ Aust $1991 ; 154: 292-3$.

7 Hill DJ. Public opinion about smoking in restaurants and at work. Med F Aust 1986; 145: 657-8.

8 Borland R, Owen N, Hill, DJ, Chapman S. Staff members' acceptance of the introduction of workplace smoking bans in the Australian public service. Med $\mathcal{F}$ Aust $1989 ; 151: 525-8$.

9 Woodward SD, Winstanley MH. Lung cancer and passive smoking at work: the Carroll case. Med f Aust $1990 ; 153: 682-4$.

10 Chapman, $\mathrm{S}$. Australian court decision on passive smoking upheld on appeal. BMF 1993; 306: 120-2.

11 Chapman S, Woodward S. Passive smoking causes lung cancer, asthma attacks, and respiratory diseases. In: Everingham R, Woodward S, eds. Tobacco litigation. Sydney: Legal Books, 1991

12 McAllister I, Moore R, Makkai T. Drugs in Australian society: patterns, attitudes and policies. Melbourne: Longman Cheshire, 1991

13 Borland R, Owen N, Hill, DJ, Chapman S. Changes in acceptance of workplace smoking bans following their implementation: a prospective study. Prev Med 1990; 19: 314-22.

14 Borland $\mathrm{R}$, Owen $\mathrm{N}$, Hocking B. Changes in smoking behaviour after a total workplace smoking ban. Aust $\mathscr{T}$ Public Health 1991; 15: 130-4.

15 Hocking B, Borland R, Owen N, Kemp G. A total ban on workplace smoking is acceptable and effective. 7 Occup Med 1991; 33: 163-7.

16 Wakefield MA, Wilson D, Owen N, Esterman A, Roberts L. Workplace smoking restrictions, occupational status, and reduced cigarette consumption $f$ Occup $\mathrm{Med}$ 1992 : 34: 693-7.

17 Borland R, Hill, DJ. Public attitudes to smoke-free zones in restaurants. Med $\mathcal{F}$ Aust 1989; 150: 407.

18 Miller $M$, Hamilton $M$, Flaherty $B$. The evaluation of Australia's National Campaign Against Drug Abuse. $\mathcal{f}$ Drug Issues 1992; 22: 487-506.

19 Makkai T, McAllister I. Patterns of drug use in Australian society. An analysis of national trend data, 1985-91. Canberra: Australian Government Publishing Service, 1993.

20 McAllister I, Makkai T. Measuring social indicators in opinion surveys: a method to improve accuracy on sensitive questions. Soc Indic Res 1992; 27 : 169-86.

21 Makkai T, McAllister I. Correcting for the underreporting of drug use in

22 McAllister I. Knowledge, attitudes and policy preferences concerning drugs in Australian society. Canberra: Australian Government Publishing Service, 1993.

23 Hill DJ, White VM, Gray NJ. Australian patterns of tobacco smoking in 1989. Med 7 Aust 1991;154: 797-801.

24 Richmond R, Heather N, Holt P, Hu W. Workplace policies and programs for tobacco, alcohol and other drugs in Australia. Canberra: Australian Government Publishing Service, National Campaign Against Drug Abuse Monograph Series No 24, 1993 .

25 Hill, DJ, White VM, Gray NJ. Measures of tobacco smoking in Australia 1974-1986 by means of a standard smoking in Australia 1974-1986 by means of a standar method. Med F Aust 1988; 149: 10-12.

26 Digits, E. A workplace smoking cessation program. A strategy with potential for mass application. Comm Health Stud 1987; 11: 45-52s.

27 Pederson L, Wanklin J, Bull S, Ashley M. A conceptual framework for the roles of legislation and education in reducing exposure to environmental tobacco smoke. $A m$ f Health Prom 1991 ; 6: 105-11. 